NBER WORKING PAPER SERIES

\title{
INHERITANCE AND SAVING
}

David Joulfaian

Working Paper 12569

http://www.nber.org/papers/w12569

\section{NATIONAL BUREAU OF ECONOMIC RESEARCH \\ 1050 Massachusetts Avenue \\ Cambridge, MA 02138 \\ October 2006}

The paper benefited from comments by Deena Ackerman, Gerald Auten, Brad Heim, and Don Kiefer. It was completed during my visit at NBER, whose support is gratefully acknowledged. The views expressed herein are those of the author(s) and do not necessarily reflect the views of the National Bureau of Economic Research.

(C) 2006 by David Joulfaian. All rights reserved. Short sections of text, not to exceed two paragraphs, may be quoted without explicit permission provided that full credit, including $@$ notice, is given to the source. 
Inheritance and Saving

David Joulfaian

NBER Working Paper No. 12569

October 2006

JEL No. E21,H31,J26

\section{ABSTRACT}

This paper explores the effects of inheritances on the saving of recipients. Information on inheritances and heirs is obtained from estate tax records of decedents which are linked to the income tax records of beneficiaries. The observed pattern of wealth mobility within two years of the receipt of inheritances and multivariate analyses show that wealth increases by less than the full amount of the inheritance received. Similarly, and consistent with previous findings, large inheritances are found to depress labor force participation.

David Joulfaian

Department of the Treasury 1500 Pennsylvania Avenue, NW

Washington, DC 20220

david.joulfaian@do.treas.gov 


\section{INTRODUCTION:}

Whether inheritances influence the saving behavior of recipients has important implications for the debate on the contribution of bequests to accumulated wealth. ${ }^{1}$ While there is little consensus on the estimated size of their contribution to wealth accumulation, the potential effects of inheritances on the consumption and labor supply of the heirs may in part determine the size of this contribution. Ignoring these potential effects may bias upward estimates of this contribution (Blinder, 1988). Indeed, while inheritances raise the recipients wealth, they may also reduce the heirs life-cycle saving and work effort.

Inheritances also have policy implications for the ongoing debate on the taxation of bequests. Ricardo (1821), for instance, hints that reductions in inheritances brought about by inheritance taxes do not affect the heir's savings. ${ }^{2}$ Others, most notably Andrew Carnegie (1891/1962, p. 56), pointed to the deleterious effects on the heirs' labor supply. ${ }^{3}$ The effects of inheritances on the recipient's behavior, however, have been the subject of very little empirical investigation.

\footnotetext{
${ }^{1}$ See Kotlikoff and Summers (1981, 1988), Modigliani (1998a, 1988b), Gale and Scholz (1994), and Brown and Weisbenner (2004).

${ }^{2}$ More specifically, and referring to inheritance taxes, Ricardo, in his Principles of Political Economy and Taxation (ch. 8), stated that “... such taxes fall on capital... If a legacy of $£ 1,000$ be subject to a tax of $£ 100$, the legatee considers his legacy as only $£ 900$ and feels no particular motive to save the $£ 100$ duty from his expenditure, and thus the capital of the country is diminished."

${ }^{3}$ Andrew Carnegie, a staunch supporter of progressive inheritance taxation, and one of the richest men of his times, argued at the turn of the twentieth century that “... The parent who leaves his son an enormous wealth generally deadens the talents and energies of the son, and tempts him to lead a less useful and worthy life than he otherwise would."
} 
In generationally-linked families, where all generations are assumed to operate under a common intertemporal budget constraint, the timing of transfers should not have a material effect on the behavior of recipients. ${ }^{4}$ However, the degree of uncertainty surrounding the size and timing of the receipt of inheritances may influence the pattern of life cycle saving (Weil, 1996). Even when fully anticipated, bequests may influence the pattern of consumption in the presence of precautionary saving and liquidity constraints. ${ }^{5}$ Some households may not be able to borrow against and collateralize their future inheritances. Thus, the magnitude and sign of the effect of inheritances on saving remains an empirical question.

The potential effects of inheritances on the behavior of the recipients have only recently been addressed in the empirical literature. Labor supply effects of inheritances, for instance, have been addressed in Holtz-Eakin, et al. (1993) who examine labor force participation pre and post the receipt of inheritances. Using estate tax records, inheritances are found to depress participation. However, using data on the elderly, Holtz-Eakin, et al. (1999) find inheritances to have little effect on retirement decisions. Joulfaian and Wilhelm (1994), using PSID panel data, explore the effects of inheritances on the recipient's hours of work. They report inheritances to have a small effect on hours of work. ${ }^{6}$

Similarly, the effects on consumption of receiving bequests have been addressed in Joulfaian and Wilhelm (1994), Weil (1994), and more recently in Brown, Coile, Weisbenner (2004). Joulfaian and Wilhem (1994), using PSID data, examine the effects of inheritances on food consumption,

\footnotetext{
${ }^{4}$ See Barro (1974) and Bernheim (1987) for opposing views.

${ }^{5}$ See Carroll and Kimball (1996 and 2001), as well as Carroll (2001) for a general discussion.
} 
the only consumption item captured in the PSID panel data. Inheritances are reported to have a small effect on consumption; consumption increases by $\$ 2-14$ for every $\$ 10,000$ in transfers received. Weil (1994), using pooled Consumer Expenditure Survey (CEX) data, explores the effects on consumption. Most recently, Brown et al. (2004) revisit the PSID data with its longer panel and broader consumption imputations, and report the receipt of inheritances to have a small effect on consumption.

In this paper I employ administrative records to explore the effects of inheritances. More specifically, I employ data on estate (inheritance) tax returns of donors linked to the income tax returns of recipients. From such administrative records, we are able to observe the circumstances of the heirs before and after the receipt of inheritances. From the income tax records, for instance, we observe pre and post-inheritance interest, dividends, and employment status. The findings suggest that wealth increases by only a fraction of the inheritances received, and imply a marginal propensity to consume $(m p c)$ significantly higher than that predicted within the perfect foresight or consumption smoothing frameworks. These results also show labor force participation to decline with the size of inheritances.

The paper is organized as follows. Section II addresses modeling issues and describes the available administrative data. Section III summarizes the empirical findings. Basic statistics on the wealth mobility before and after the receipt of an inheritance are reported, followed by findings from multivariate analyses on reported wealth and labor force participation. A concluding comment is provided in Section IV.

\footnotetext{
${ }^{6}$ The effects on entrepreneurship are addressed in Holtz-Eakin, et al. (1994a, 1994b) and Blanchflower and Oswald (1998).
} 


\section{MODELING AND DATA ISSUES}

To motivate the analysis, consider a household that lives for $T$ periods and leaves no bequests. In each period $t$ the household earns income $y_{t}$ and consumes $c_{t}$. The household has initial wealth of zero, and receives inheritances B in period $n$. The household maximizes lifetime utility:

$U(c)=\sum_{t=1}^{T} \beta^{t-1} u\left(c_{t}\right)$

where $\beta$ is the household intertemporal discount rate. This lifetime utility is maximized subject to the constraint that the present discounted value of lifetime consumption $\left(c_{1}, \ldots, c_{T}\right)$ equals the present value of lifetime earnings $\left(y_{1}, \ldots, y_{T}\right)$ plus inheritance $\mathrm{B}$, which is received in period $n<T$, or:

$\sum_{t=1}^{T} \frac{C_{t}}{(1+r)^{t-1}}=\frac{B_{n}}{(1+r)^{n-1}}+\sum_{t=1}^{T} \frac{y_{t}}{(1+r)^{t-1}}$

Making the very simplifying assumption that $\beta=1 /(1+r)$, then the special case Euler equation yields:

$c_{1}=\ldots c_{n}=\ldots c_{T}$

Assuming earnings are exogenously predetermined, and the amount of inheritances is known with certainty (with no borrowing constraints), then inheritances are consumed over $T$ periods, 
and the timing of their receipt does not alter the consumption path. At the end of period $n$, wealth W is changed by the full amount of inheritance received. More specifically:

$$
W_{n}=y_{n}+(1+r) W_{n-1}+B_{n}-c_{n}
$$

Given that earnings and consumption in period $t$ are predetermined, then wealth $W$ increases by the amount of inheritance $B$. Alternatively stated, the $m p c$ of inherited wealth is about zero.

If inheritances are completely unanticipated, or that liquidity constraints are binding, then the consumption path becomes:

$$
c_{1}=\ldots=c_{n-1}<c_{n}=\ldots=c_{T}
$$

Here there is an abrupt shift in the consumption path, and inheritances, with appropriate discounting, are consumed uniformly over the periods $T-n$. At the end of period $n$, wealth increases by the amount of the inheritance less $B /(T-n)$, again assuming consumption smoothing. The mpc out of inherited wealth is $1 /(T-n)>0$. This value, of course, will change once we let $\beta \neq 1 /(1+r)$.

Of interest is how saving or wealth evolves in the aftermath of inheritance receipt. If $\partial \mathrm{W}_{\mathrm{t}} / \partial \mathrm{B}_{\mathrm{t}}=$ 1, implying an $m p c$ of zero as in (3), then inheritances are likely to have been fully anticipated and liquidity constraints may not be binding. If, on the other hand, $\partial W_{t} / \partial B_{t}\langle 1$, then wealth increases by less than the full amount of inheritances for an $m p c$ greater than zero, as in (5). Of 
course, if consumption smoothing does not explain consumer behavior (Carroll, 2001), the behavioral response may also vary, but either way, the effect of inheritances remains an empirical question.

\section{The Data}

I employ administrative data to explore how inheritances influence the saving behavior of recipients. The data consist of a sample of matched estate tax returns of donors and income tax returns of heirs. The starting point is a sample of estate tax returns for decedents in 1989, where the wealthy are over represented, linked to the income tax returns of heirs for the years before and after the receipt of an inheritance. More specifically, the income tax returns are for tax years 1988 through $1991 .^{7}$ From estate tax returns we obtain information on the amount of bequests to heirs. We also obtain information on lifetime gifts made by donors. Using beneficiary information reported on the estate tax return, more specifically social security numbers, the heirs' income tax returns are obtained. The latter provide information on the various sources of labor and capital income. The data is further augmented by age from social security records. In many ways this is similar to the data on 1982 decedents employed in Holtz-Eakin, et al. (1993, 1994a, 1994b) and Joulfaian and Wilhem (1994).

A number of observations are excluded from the sample. Heirs under the age of 21 or over the age of 59 in 1989, for instance, are excluded from the sample to control for the effects of normal

\footnotetext{
${ }^{7}$ Given delays in closing an estate, much of the inheritances are likely to have been received in late 1989 and 1990.
} 
labor force entry and retirement decisions. Similarly, individuals with partnership income and losses are excluded from the sample. ${ }^{8}$

Administrative records such as income tax returns have many advantages over survey data. But their primary shortcoming is that consumption and wealth information are not reported on tax returns. What is available is information on the flow of income or return to such assets. Information is available on wages, self-employment income, interest, and dividends among others. As such, wealth is constructed as the capitalized value of interest and dividend income. Interest income is capitalized using interest rates of 0.0826 in 1988 , and 0.0682 and 0.0826 for the years 1990 and 1991. Similarly, dividends are capitalized using dividend yields of 0.0364 in 1988 and 0.0361 and 0.0324 for 1990 and $1991 .{ }^{9}$ Wealth is defined as the sum of these capitalized values. Because inheritances are stated in $\$ 1989$, the wealth measures are also stated in $\$ 1989$.

The resulting sample consists of 819 observations of matched estate and income tax returns pairing donors and heirs. Table 1 provides a summary of sample attributes. The mean preinheritance wealth is $\$ 171,500$ ( $\mathrm{sd}=649,300$ ) compared to a post-inheritance wealth of $\$ 443,100$ ( $\mathrm{sd}=1,555,000$ ), both measured in $\$ 1989$. The average increase in wealth is $\$ 271,600$ ( $s d=1,280,000)$, compared to a mean inheritance of $\$ 327,000$ ( $s d=1,183,800)$. The unconditional mean earnings are $\$ 36,300$ (sd=55,500) prior to receiving an inheritance compared to $\$ 34,000$

\footnotetext{
${ }^{8}$ These are individuals who file Schedule E of the US income tax return. Holtz-Eakin et al (1994a) demonstrate the uniqueness of individuals with partnership income.

${ }^{9}$ Interest rates reflect the yield on 3-year Treasury bonds, while the dividend yield reflects the S\&P dividend price ratio.
} 
$(s d=54,500)$ in the aftermath of an inheritance. ${ }^{10}$ About 91 percent are in the labor force prior to the receipt of an inheritance, compared to 87 percent post-inheritance. The average age of the primary taxpayer is 38 years ( $\mathrm{sd}=10)$, and about 44 percent of the recipients are married. The average number of dependents is $0.64(\mathrm{sd}=1.02)$.

Roughly a third of the observations received inheritances of less than $\$ 25,000$. Another third received inheritances of between $\$ 25,000$ and $\$ 150,000$, and the remainder received transfers in excess of $\$ 150,000$. For those in the lowest inheritance group, the mean pre- inheritance wealth is $\$ 67,200$ ( $s d=165,700$ ), compared to a post inheritance wealth of $\$ 131,600$ ( $s d=466,200$ ). The average wealth increase is $\$ 64,400$ ( $\mathrm{sd}=411,600$ ), several times the mean inheritance of $\$ 9,400$ ( $s d=5,000)$. The pre and post-inheritance mean earnings are $\$ 32,900$ (sd=51,600) and $\$ 36,800$ (sd=47,600), respectively.

Turning to the middle inheritance group, the mean pre-inheritance wealth is $\$ 165,500$ ( $s d=929,100)$, compared to a post inheritance wealth of $\$ 317,500$ ( $s d=1,401,900)$. The average wealth increase is $\$ 152,000$ ( $\mathrm{sd}=732,700$ ), slightly over twice the average inheritance received of $\$ 71,700(\mathrm{sd}=37,300)$. The pre and post inheritance earnings are $\$ 34,500(\mathrm{sd}=43,400)$ and $\$ 30,000$ (sd=34,700), respectively. The average age of recipients is 37.9 year ( $\mathrm{sd}=10.32$ ), about the same as the low inheritance group.

For the highest inheritance group, pre and post-inheritance wealth are $\$ 275,100$ (sd=570,600) and $\$ 861,300$ ( $s d=2,150,000$ ), respectively. The average change in wealth is $\$ 586,200$

${ }^{10}$ Earnings are defined as the sum of wages and net income (or loss) from proprietorships and farms, all stated in $\$ 1989$. 
( $s d=1,995,900)$, much smaller than the mean inheritance received of $\$ 881,900$ (sd=1,150,100).

The pre and post- inheritance earnings are $\$ 41,300$ ( $\mathrm{sd}=68,300)$ and $\$ 35,500$ ( $\mathrm{sd}=73,500$ ), respectively. This group is slightly older with mean age of 40.06 ( $\mathrm{sd}=9.97)$.

\section{EMPIRICAL FINDINGS}

\section{Basic Statistics}

The figures reported in the last three columns of Table 1 show that the average change in wealth, relative to the size of inheritance received, declines with the size of the transfer. As noted earlier, the wealth increased by an average of $\$ 586,200$ for the high inheritance group which received an average inheritance of $\$ 881,900$, compared to the low inheritance group which received an average inheritance of $\$ 9,400$ but experienced an average increase in wealth of $\$ 64,400$.

Similarly, we observe a reduction in the labor participation rate and a concomitant reduction in earnings, as we move from the low to the high inheritance group.

In order to further explore the effects of inheritance, next I examine the wealth mobility in the sample and contrast the observed pattern for the three inheritance groups. For each inheritance group in Table 1, the sample is divided into three wealth classes: (1) under $\$ 25,000$ for the low wealth group, (2) $\$ 25,000$ to $\$ 150,000$, (3) and over $\$ 150,000$ for the high wealth group. For period two, post-inheritance wealth is reduced by the amount of inheritance received to allow for intertemporal comparisons. 
Table 2 reports transition matrices which summarize the wealth mobility in the sample for each of the three inheritance groups. The top panel, for instance, examines the mobility of those in the low inheritance group. Each row shows the number of observations in the pre and postinheritance period for each wealth class. The cell in row one and column one shows that 122 individuals, with inheritance under $\$ 25,000$, enjoyed the same wealth (under $\$ 25,000$ ) in the two periods. Another 28, or 18 percent migrated to the next wealth class, and another 8 (five percent) moved to the wealthiest class. Of those in wealth class 2, i.e. the middle wealth group, 25 percent moved to the lower wealth category and another 16 percent moved up. Little mobility is observed in the third group; 96 percent remain in the top class.

Moving to the mid level inheritance group in the middle panel of Table 2, those receiving inheritances between $\$ 25,000$ and $\$ 150,000$, we observe a greater wealth mobility. The middle panel of Table 2 shows that only 86 percent (36 observations) of those in the wealthiest group maintained their position in the post-inheritance period. For those in the middle, only 40 percent (32 observations) maintained their position, with 31 percent moving down and 29 percent moving up.

The greatest mobility is observed for those in the high inheritance group and receiving over $\$ 150,000$. The bottom panel of Table 2 , shows that 79 percent (96 observations) of the least wealthy maintained their position over the two periods (those in row one column one). This is virtually identical to those in the top and middle panels. For those in the middle wealth category, 67 percent (45 observations) moved to the lower wealth class. Only 58 percent (52 observations) of the wealthiest group maintained its position, down from 86 and 96 percent in the middle and 
top panels, respectively. Some 31 percent, or 28 observations, migrated to the least wealthy group, compared to the 3.85 percent (inheritance< $\$ 25,000$ ) and 2.30 percent ( $\$ 25,000 \leq$ inheritance $\leq \$ 150,000)$ observed for the smaller inheritance groups.

\section{Multivariate Analysis}

The discussion surrounding Tables 1 and 2 suggests that large inheritances depress saving. To better gauge the effects of inheritances, next I employ multivariate analysis. Column 1 of Table 3 reports results from a simple regression of the change in pre and post-inheritance wealth on inheritance received. ${ }^{11}$ The estimated coefficient on the latter is 0.79 with a standard error of 0.03. This suggests that wealth increases by only $\$ 0.79$ for every dollar in inheritance received. Alternatively stated, individuals consume 21 percent of the inheritance received. With an adjusted $\mathrm{R}$ squared of 0.53 , inheritances seem to explain quite a bit of the observed change in wealth.

Column 2 adds a number of control variables. These include demographic variables such as age, marital status, and number of dependents. They also include other variables, such as lagged wealth and an indicator for past lifetime gifts by the donor, to control for preferences for saving and inheritance expectations. With the expanded specification, the estimated coefficient on inheritances remains invariant to the addition of these control variables. The estimated coefficient becomes 0.77 (se=0.03) in column (2), virtually unchanged from the value reported in column (1). The estimated coefficient on lifetime gifts by the donor is negative but not precisely

\footnotetext{
${ }^{11}$ Unlike the definition employed in Table 2, wealth here is not reduced by inheritances.
} 
measured. The coefficients on the quadratic age term are also not precisely measured. Neither are they jointly significant $\left(\chi^{2}=1.1359\right.$ with 0.5667 significance). The coefficient on the number of dependents is negative and significant. On the other hand, the coefficient on being married is positive and significant. The adjusted R squared slightly increases from 0.527 to 0.553 when control variables are added. With the estimated coefficient on inheritance under one, these findings suggest that for every additional dollar of inheritance received, recipients consume more than $\$ 0.20$.

Given that the sample over represents the wealthiest of estates, and, hence, recipients of large inheritances, columns (1) and (2) are re-estimated with the observations re-weighted to reflect the estate tax filing population. The revised estimates are reported in columns (3) and (4). Beginning with the simple regression of the change in wealth on the amount of inheritance received, the estimated coefficient declines to 0.60 ( $\mathrm{se}=0.03)$, from the earlier estimate of 0.79 (se=0.03). The new estimated coefficient retains its value when the control variables are considered, with a value of $0.59(\mathrm{se}=0.03)$. The implied $m p c$ from the weighted regressions is about 0.40 .

The above results, particularly those in column (2), point to a potential difference in the change in wealth experienced by single and married households. To further gain insights into the behavior of married and single households, Table 3 is reproduced and the estimates separately reported in Tables 4A and 4B for each of the two groups. Beginning with singles in Table 4A, the estimated coefficients vary little between the two specifications; the implied $m p c$ is about 0.30. The estimated coefficient in the linear regression is 0.6927 ( $\mathrm{se}=0.0341$ ). Adding the 
control variables in column (2) has little effect, and the coefficient is estimated at 0.6836 (se=0.0336). Also weighting the sample to reflect the population filing estate tax returns has little effect on the estimates. Heirs seem to consume some 30 percent of the inherited wealth.

Moving to Table 4B, and using the un-weighted observations, inheritances seem to have little if any depressing effects on savings. Both columns (1) and (2) report estimated coefficients of slightly greater than one on the inheritance variable. However, when the sample is weighted to reflect the population filing estate tax returns, the estimated coefficients become much smaller; 0.46 (se=0.04) in column (3), and $0.48(0.05)$ in column (4). The latter imply an $m p c$ of about 0.50 .

\section{Labor Force Participation}

Given the noisy measure of wealth employed in this paper, and its reliance on financial wealth, one may attribute the above findings to measurement error. As such, I also explore the effects on labor force participation as well, as earnings may not be exogenous to the receipt of inheritances. Here another limitation of the data is that only household and not individual earnings are observed. Thus, for married households we are unable to observe whether one or two are in the labor force. Thus, by necessity, the focus is on single household labor force participation.

Table 5 reports findings from Logit estimates for labor force participation for singles. Column (1) includes the effects of inheritances only. The estimated coefficient on the latter is -0.289 ( $\mathrm{se}=0.10)$, and implies a marginal effect of -0.048 ( $\mathrm{se}=0.017)$. In column (2) a number of control 
variables are considered. These include lagged participation, lagged earnings, and demographic variables. The coefficient on inheritance becomes -0.310 ( $\mathrm{se}=0.097$ ), consistent with the findings in column 1 ; the marginal effect is $-0.045(\mathrm{se}=0.015) .{ }^{12}$ The coefficient on pre-inheritance participation is 2.141 (se=0.328) with marginal effect of 0.311 (0.051). Similarly, lagged earnings have a positive effect on participation with an estimated coefficient of 7.014 (se=3.6701). The coefficients on age, entered in quadratic form, are not significant. However, they are jointly significant ( $\chi^{2}=7.89$ with 0.019 significance). The coefficients on both preinheritance wealth and the presence of indicator for lifetime gifts are negative, but imprecisely measured. $^{13}$

When the observations are weighted, the estimated effects of inheritances change little as shown in column (3). The estimated coefficient on inheritances becomes -2.66 (se=0.85), with an estimated marginal effect of -0.035 (se=0.018). ${ }^{14}$ An inheritance of $\$ 1$ million, other things equal, reduces labor force participation by about 11 percent.

\section{CONCLUSION}

This paper employed administrative records to explore the effects of inheritances on wealth accumulation. The findings suggest that the wealth of the recipient increases by less than the full

\footnotetext{
12 Replacing the level of inheritance with its natural log yields a coefficient of -0.302 (se=0.065), with marginal effects of -0.048 (se=0.01), in column (1), and a coefficient of -0.251 (se=0.074), with marginal effects of -0.0359 (se=0.01), in column (2).

13 The mean values for the regressors are: inheritance 0.3821 ( $\mathrm{sd}=1.3745)$, age 36.98 ( $\mathrm{sd}=10.80)$, lagged wealth 0.1896 ( $s d=0.8015)$, earnings 0.0206 ( $s d=0.0424)$, number of dependents $0.1725(s d=0.5443)$, presence of lifetime gifts 0.3908, and percent employed in 1988 of 0.8603 , and 0786 in 1991.
} 
amount of the inheritance received. Basic statistics show that those with wealth over $\$ 150,000$ are about 10 times more likely to experience a reduction in pre-inheritance wealth when they inherit more than $\$ 150,000$ (mean $\$ 881,900$ ) compared to inheriting less than $\$ 25,000$ (mean $(\$ 9,400)$.

Multivariate analyses reinforce the observed pattern of wealth mobility for various inheritance sizes. Findings from such analyses show that on average, wealth increases by much less than the full inheritance received. Inheritances are also demonstrated to have labor supply effects.

The findings are subject to a number of limitations. The estimate of wealth may suffer from measurement error. Households may invest their wealth in assets that reflect different liquidity preferences and maturities. Thus it may not be appropriate to apply one rate of return to all recipients of interest (and dividend) income. Furthermore, the wealth measure includes only financial wealth, even though individuals may hold real estate, business interests, or other types of assets in their portfolios. However, findings on labor force participation are less susceptible to such measurement errors and provide further support to the above findings.

\footnotetext{
14 The mean values for the weighted regressors are: inheritance 0.125 (sd=0.343), age 38.78 ( $\mathrm{sd}=10.77)$, lagged wealth 0.058 ( $\mathrm{sd}=0.223$ ), earnings 0.022 ( $\mathrm{sd}=0.045)$, number of dependents 0.095 ( $\mathrm{sd}=0.346)$, presence of lifetime gifts 0.072, and percent employed in 1988 of 0.907, and 0.914 in 1991.
} 


\section{REFERENCES}

Blanchflower, David G. and Andrew J. Oswald. “What Makes an Entrepreneur?” Journal of Labor Economics 16:1, January 1998, pp. 26-60.

Brown, Jeffrey R., Courtney C. Coile, and Scott J. Weisbenner, Effects of Inheritance on Receipts, University of Illinois at Urbana-Champaign, 2004, mimeo.

Brown, Jeffrey R. and Scott J. Weisbenner. Intergenerational Transfers and Savings Behavior; Perspectives on the economics of aging, NBER Conference Report series. Chicago and London: University of Chicago Press, 2004, pp. 181-201.

Carnegie, Andrew. "The Advantages of Poverty" in the Gospel of Wealth and other Timely Essays, Edward C Kirkland, ed., The Belknap Press of Harvard University Press, Cambridge, MA, 1962.

Carroll, Christopher D.; Kimball, Miles S. "Liquidity Constraints and Precautionary Saving," NBER Working Paper 8496, 2001.

Carroll, Christopher D.; Kimball, Miles S. On the Concavity of the Consumption Function; By; Econometrica 64:4, July 1996, pp. 981-92

Carroll, Christopher D. “A Theory of the Consumption Function, With and Without Liquidity Constraints (Expanded Version)”, NBER Working Paper 8387, 2001.

Gale, William G. and John Karl Scholz, "Intergenerational Transfers and the Accumulation of Wealth,” The Journal of Economic Perspectives 8:4, Fall 1994, pp. 145-160.

Holtz-Eakin, Douglas, David Joulfaian, and Harvey Rosen, "Estimating the Income Effect on Retirement," Aging Studies Program Paper No. 18, April 1999, Syracuse University.

Holtz-Eakin, Douglas, David Joulfaian, and Harvey Rosen,"Entrepreneurial Decisions and Liquidity Constraints," The Rand Journal of Economics, Summer 1994a, pp. 334-347.

Holtz-Eakin, Douglas, David Joulfaian, and Harvey Rosen. "Sticking it Out: Entrepreneurial Survival and Liquidity Constraints,” Journal of Political Economy, February 1994b, pp. 53-75.

Holtz-Eakin, Douglas, David Joulfaian, and Harvey Rosen. “The Carnegie Conjecture: Some Empirical Evidence,” Quarterly Journal of Economics, May 1993, pp. 413-436.

Joulfaian, David and Mark Wilhelm. “Inheritance and Labor Supply,” The Journal of Human Resources, Fall 1994, pp. 1205-1234.

Ricardo, David. On the Principles of Political Economy and Taxation, London: John Murray, 1821, Third edition. http://www.econlib.org/library/Ricardo/ricP.html 
Weil, David N. "Intergenerational Transfers, Aging, and Uncertainty,” in David Wise, ed., Advances in the Economics of Aging, University of Chicago Press, 1996.

Weil, David N. "Saving of the Elderly in Micro and Macro Data," The Quarterly Journal of Economics 109:1, February 1994, 55-81. 
Table 1

Descriptive Statistics for Select Variables

(Sample mean followed by the standard deviation in parentheses)

\begin{tabular}{|l|c|c|c|c|}
\hline Variable & All & $\begin{array}{c}\text { Inheritance } \\
<\$ 25,000\end{array}$ & $\begin{array}{c}\$ 25,000 \leq \\
\text { Inheritance } \\
\leq \$ 150,000\end{array}$ & $\begin{array}{c}\text { Inheritance } \\
>\$ 150,000\end{array}$ \\
\hline Age & 38.4298 & 37.2308 & 37.9181 & 40.0683 \\
& $(10.3899)$ & $(10.7197)$ & $(10.3204)$ & $(9.9681)$ \\
\hline 1988 Wealth & 0.1715 & 0.0672 & 0.1655 & 0.2751 \\
& $(0.6493)$ & $(0.1657)$ & $(0.9291)$ & $(0.5706)$ \\
\hline 1991 Wealth & 0.4431 & 0.1316 & 0.3175 & 0.8613 \\
& $(1.5500)$ & $(0.4662)$ & $(1.4019)$ & $(2.1500)$ \\
\hline Change in Wealth & 0.2716 & 0.0644 & 0.1520 & 0.5862 \\
& $(1.2801)$ & $(0.4116)$ & $(0.7327)$ & $(1.9959)$ \\
\hline Inheritance & 0.3269 & 0.0094 & 0.0717 & 0.8819 \\
& $(1.1838)$ & $(0.0050)$ & $(0.0373)$ & $(1.1501)$ \\
\hline 1988 Earnings & 0.0363 & 0.0329 & 0.0345 & 0.0413 \\
& $(0.0555)$ & $(0.0516)$ & $(0.0434)$ & $(0.0683)$ \\
\hline 1991 Earnings & 0.0340 & 0.0368 & 0.0300 & 0.0355 \\
& $(0.0545)$ & $(0.0476)$ & $(0.0347)$ & $(0.0735)$ \\
\hline Dummy Lifetime Gifts & 0.3687 & 0.4115 & 0.3701 & 0.3273 \\
\hline In Labor Force in 1988 & 0.9096 & 0.9385 & 0.9075 & 0.8849 \\
\hline In Labor Force in 1991 & 0.8681 & 0.9192 & 0.8790 & 0.8094 \\
\hline Married & 0.4408 & 0.4385 & 0.4342 & 0.4496 \\
\hline Dependents & 0.6386 & 0.6077 & 0.6014 & 0.7050 \\
& $(1.0200)$ & $(0.9903)$ & $(0.9661)$ & $(1.0978)$ \\
\hline Observations & 819 & 260 & 281 & 278 \\
\hline
\end{tabular}

Wealth, inheritance, and earnings, are stated in \$1989 millions. Sample restricted to those age 21 to 59 in 1989. 
Table 2

Wealth Mobility and Size of Inheritance

(Each cell contains number of observations, row percent and its standard deviation)

\begin{tabular}{|c|c|c|c|c|}
\hline Year & & \multicolumn{3}{|c|}{1991} \\
\hline \multicolumn{5}{|c|}{ Low Inheritance Group: Inheritance $<\$ 25,000$} \\
\hline \multirow{4}{*}{1988} & Wealth* & $<\$ 25,000$ & $\begin{array}{c}\$ 25,000 \leq \\
\leq \$ 150,000\end{array}$ & $>\$ 150,000$ \\
\hline & $<\$ 25,000$ & $\begin{array}{c}122 \\
0.7722 \\
(0.0334) \\
\end{array}$ & $\begin{array}{c}28 \\
0.1772 \\
(0.0304) \\
\end{array}$ & $\begin{array}{c}8 \\
0.0506 \\
(0.0174) \\
\end{array}$ \\
\hline & $\begin{array}{l}\$ 25,000 \leq \\
\leq \$ 150,000\end{array}$ & $\begin{array}{c}19 \\
0.2500 \\
(0.0497) \\
\end{array}$ & $\begin{array}{c}45 \\
0.5921 \\
(0.0564) \\
\end{array}$ & $\begin{array}{c}12 \\
0.1579 \\
(0.0418) \\
\end{array}$ \\
\hline & $>\$ 150,000$ & $\begin{array}{c}1 \\
0.0385 \\
(0.0377) \\
\end{array}$ & $\begin{array}{l}-- \\
-- \\
-- \\
\end{array}$ & $\begin{array}{c}25 \\
0.9615 \\
(0.0377) \\
\end{array}$ \\
\hline \multicolumn{5}{|c|}{ Middle Inheritance Group: $\$ 25,000 \leq$ Inheritance $\leq \$ 150,000$} \\
\hline \multirow{4}{*}{1988} & Wealth* & $<\$ 25,000$ & $\begin{array}{l}\$ 25,000 \leq \\
\leq \$ 150,000\end{array}$ & $>\$ 150,000$ \\
\hline & $<\$ 25,000$ & $\begin{array}{c}119 \\
0.7484 \\
(0.0344) \\
\end{array}$ & $\begin{array}{c}16 \\
0.1006 \\
(0.0239) \\
\end{array}$ & $\begin{array}{c}24 \\
0.1509 \\
(0.0284) \\
\end{array}$ \\
\hline & $\begin{array}{c}\$ 25,000 \leq \\
\leq \$ 150,000\end{array}$ & $\begin{array}{c}25 \\
0.3125 \\
(0.0518) \\
\end{array}$ & $\begin{array}{c}32 \\
0.4000 \\
(0.0548) \\
\end{array}$ & $\begin{array}{c}23 \\
0.2875 \\
(0.0506) \\
\end{array}$ \\
\hline & $>\$ 150,000$ & $\begin{array}{c}1 \\
0.0230 \\
(0.0231)\end{array}$ & $\begin{array}{c}5 \\
0.1190 \\
(0.0500)\end{array}$ & $\begin{array}{c}36 \\
0.8571 \\
(0.0540)\end{array}$ \\
\hline \multicolumn{5}{|c|}{ High Inheritance Group: Inheritance $>\$ 150,000$} \\
\hline \multirow{4}{*}{1988} & Wealth* & $<\$ 25,000$ & $\begin{array}{c}\$ 25,000 \leq \\
\leq \$ 150,000\end{array}$ & $>\$ 150,000$ \\
\hline & $<\$ 25,000$ & $\begin{array}{c}96 \\
0.7869 \\
(0.0371)\end{array}$ & $\begin{array}{c}10 \\
0.082 \\
(0.0248)\end{array}$ & $\begin{array}{c}16 \\
0.1311 \\
(0.0306)\end{array}$ \\
\hline & $\begin{array}{l}\$ 25,000 \leq \\
\leq \$ 150,000 \\
\end{array}$ & $\begin{array}{c}45 \\
0.6716 \\
(0.0574) \\
\end{array}$ & $\begin{array}{c}8 \\
0.1194 \\
(0.0396) \\
\end{array}$ & $\begin{array}{c}14 \\
0.2090 \\
(0.0497) \\
\end{array}$ \\
\hline & $>\$ 150,000$ & $\begin{array}{c}28 \\
0.3146 \\
(0.0492) \\
\end{array}$ & $\begin{array}{c}9 \\
0.1011 \\
(0.0320)\end{array}$ & $\begin{array}{c}52 \\
0.5843 \\
(0.0522) \\
\end{array}$ \\
\hline
\end{tabular}

* Wealth is stated in \$1989, and the 1991 level is reduced by inheritances in this table. 
Table 3

Inheritance and Change in Wealth: OLS Estimates

(Standard Errors in Parentheses)

\begin{tabular}{|l|c|c|c|c|}
\hline Variable & $(1)$ & $(2)$ & $\begin{array}{c}\text { Weighted } \\
(3)\end{array}$ & $\begin{array}{c}\text { Weighted } \\
(4)\end{array}$ \\
\hline \multirow{2}{*}{ Intercept } & 0.0148 & 0.0721 & 0.0122 & -0.1451 \\
& $(0.0319)$ & $(0.4454)$ & $(0.0101)$ & $(0.1484)$ \\
\hline \multirow{2}{*}{ Inheritance } & $0.7855^{*}$ & $0.7738^{*}$ & $0.5967^{*}$ & $0.5856^{*}$ \\
& $(0.0260)$ & $(0.0257)$ & $(0.0295)$ & $(0.0304)$ \\
\hline \multirow{2}{*}{ Lagged Wealth } & -- & $0.2896^{*}$ & -- & $0.2054^{*}$ \\
& -- & $(0.0472)$ & -- & $(0.0543)$ \\
\hline \multirow{2}{*}{ Dummy Lifetime Gifts } & -- & -0.0255 & -- & 0.0015 \\
& -- & $(0.0633)$ & -- & $(0.0303)$ \\
\hline \multirow{2}{*}{ Age } & -- & -0.0028 & -- & 0.0106 \\
& -- & $(0.0235)$ & -- & $(0.0077)$ \\
\hline \multirow{2}{*}{ Age ${ }^{2} .10^{-2}$} & -- & -0.0005 & -- & -0.0150 \\
& -- & $(0.0291)$ & -- & $(0.0094)$ \\
\hline \multirow{2}{*}{ Dependents } & -- & $-0.0902^{*}$ & -- & -0.0062 \\
& -- & $(0.0363)$ & -- & $(0.0114)$ \\
\hline \multirow{2}{*}{ Married } & -- & $0.1778^{*}$ & -- & -0.0334 \\
& -- & $(0.0718)$ & -- & $(0.0215)$ \\
\hline $\mathrm{R}^{2}$ & 0.5272 & 0.5480 & 0.3335 & 0.3478 \\
\hline Observations & 819 & 819 & 819 & 819 \\
\hline
\end{tabular}

Dependent variable is change in wealth between 1988 and 1991. Inheritance, wealth, and earnings, are in millions of $\$ 1989$.

* Significant at the 5 percent level. 


\section{Table 4A}

Inheritance and Change in Wealth: Estimates for Single Households (Standard Errors in Parentheses)

\begin{tabular}{|l|c|c|c|c|}
\hline Variable & $(1)$ & $(2)$ & $\begin{array}{c}\text { Weighted } \\
(3)\end{array}$ & $\begin{array}{c}\text { Weighted } \\
(4)\end{array}$ \\
\hline \multirow{2}{*}{ Intercept } & $\begin{array}{c}0.0225 \\
(0.0486)\end{array}$ & $\begin{array}{c}-0.1384 \\
(0.6009)\end{array}$ & $\begin{array}{c}0.0202 \\
(0.0145)\end{array}$ & $\begin{array}{c}0.0016 \\
(0.1843)\end{array}$ \\
\hline Inheritance & $\begin{array}{c}0.6927 \\
(0.0341)\end{array}$ & $\begin{array}{c}0.6836^{*} \\
(0.0336)\end{array}$ & $\begin{array}{c}0.7066^{*} \\
(0.0397)\end{array}$ & $\begin{array}{c}0.6796^{*} \\
(0.0397)\end{array}$ \\
\hline \multirow{2}{*}{ Lagged Wealth } & -- & $0.3110^{*}$ & -- & $0.2854^{*}$ \\
& -- & $(0.0580)$ & -- & $(0.0605)$ \\
\hline \multirow{2}{*}{ Dummy Lifetime Gifts } & -- & -0.0622 & -- & 0.0029 \\
& -- & $(0.0950)$ & -- & $(0.0521)$ \\
Age & -- & 0.0139 & -- & 0.0028 \\
& -- & $(0.0323)$ & -- & $(0.0098)$ \\
\hline Age ${ }^{2} .10^{-2}$ & -- & -0.0240 & -- & -0.0058 \\
& -- & $(0.0409)$ & -- & $(0.0122)$ \\
\hline \multirow{2}{*}{ Dependents } & -- & $-0.1708^{*}$ & -- & $-0.0797 *$ \\
& -- & $(0.0868)$ & -- & $(0.0387)$ \\
\hline $\mathrm{R}^{2}$ & 0.4741 & 0.5028 & 0.4104 & 0.4467 \\
\hline Observations & 458 & 458 & 458 & 458 \\
\hline
\end{tabular}

Dependent variable is change in wealth between 1988 and 1991. Inheritance, wealth, and earnings, are in millions of \$1989.

* Significant at the 5 percent level. 
Table 4B

Inheritance and Change in Wealth: Estimates for Married Households (Standard Errors in Parentheses)

\begin{tabular}{|l|c|c|c|r|}
\hline \multicolumn{1}{|c|}{ Variable } & $(1)$ & $(2)$ & $\begin{array}{c}\text { Weighted } \\
(3)\end{array}$ & $\begin{array}{c}\text { Weighted } \\
(4)\end{array}$ \\
\hline \multirow{2}{*}{ Intercept } & -0.0250 & 0.1163 & 0.0134 & -0.3067 \\
& $(0.0347)$ & $(0.6571)$ & $(0.0139)$ & $(0.2490)$ \\
\hline \multirow{2}{*}{ Inheritance } & $1.0777^{*}$ & $1.0638^{*}$ & $0.4616^{*}$ & $0.4781^{*}$ \\
& $(0.0378)$ & $(0.0384)$ & $(0.0428)$ & $(0.0465)$ \\
\hline \multirow{2}{*}{ Lagged Wealth } & -- & 0.1494 & -- & -0.1386 \\
& -- & $(0.0920)$ & -- & $(0.1181)$ \\
\hline \multirow{2}{*}{ Dummy Lifetime Gifts } & -- & 0.0312 & -- & 0.0055 \\
& -- & $(0.0712)$ & -- & $(0.0367)$ \\
\hline \multirow{2}{*}{ Age } & -- & -0.0073 & -- & 0.0163 \\
& -- & $(0.0335)$ & -- & $(0.0128)$ \\
\hline \multirow{2}{*}{ Age ${ }^{2} .10^{-2}$} & -- & 0.0109 & -- & -0.0191 \\
& -- & $(0.0400)$ & -- & $(0.0154)$ \\
\hline \multirow{2}{*}{ Dependents } & -- & -0.0522 & -- & -0.0051 \\
\hline $\mathrm{R}^{2}$ & -- & $(0.0317)$ & -- & $(0.0125)$ \\
\hline Observations & 0.6929 & 0.6948 & 0.2427 & 0.239 \\
\hline
\end{tabular}

Dependent variable is change in wealth between 1988 and 1991. Inheritance, wealth, and earnings, are in millions of $\$ 1989$.

* Significant at the 5 percent level; ** at the 10 percent level. 
Table 5

Inheritance and Labor Force Participation: Logit Estimates for Singles (Standard Errors in Parentheses)

\begin{tabular}{|l|c|c|c|c|c|}
\hline \multicolumn{1}{|c|}{ Variable } & $(1)$ & $(2)$ & $\begin{array}{c}\text { Marginal } \\
\text { Effects }\end{array}$ & $\begin{array}{c}\text { Weighted } \\
(3)\end{array}$ & $\begin{array}{c}\text { Marginal } \\
\text { Effects }\end{array}$ \\
\hline \multirow{2}{*}{ Intercept } & $1.4256^{*}$ & 3.0205 & 0.4393 & $17.2650^{*}$ & $0.2278^{*}$ \\
& $(0.1220)$ & $(1.8489)$ & $(0.2647)$ & $(6.8043)$ & $(0.0830)$ \\
\hline \multirow{2}{*}{ Inheritance } & $-0.2887^{*}$ & $-0.3070^{*}$ & $-0.0446^{*}$ & $-2.6623^{*}$ & $-0.0351^{* *}$ \\
& $(0.0996)$ & $(0.0995)$ & $(0.0147)$ & $(0.8461)$ & $(0.0184)$ \\
\hline \multirow{2}{*}{ Lagged Participation } & -- & $2.1414^{*}$ & $0.3114^{*}$ & $2.2999^{*}$ & $0.0303^{* *}$ \\
& -- & $(0.3282)$ & $(0.0508)$ & $(0.4957)$ & $(0.0172)$ \\
\hline \multirow{2}{*}{ Lagged Earnings } & -- & $7.0138^{* *}$ & $1.0200^{* *}$ & $62.8530^{*}$ & $0.8292^{*}$ \\
& -- & $(3.6711)$ & $(0.5347)$ & $(19.5580)$ & $(0.4148)$ \\
\hline \multirow{2}{*}{ Lagged Wealth } & -- & -0.1629 & -0.0237 & $3.4014^{*}$ & $0.0449^{* *}$ \\
& -- & $(0.1732)$ & $(0.0252)$ & $(1.2927)$ & $(0.0252)$ \\
\hline \multirow{2}{*}{ Dummy Lifetime Gifts } & -- & -0.2053 & -0.0298 & -0.2485 & -0.0033 \\
& -- & $(0.2709)$ & $(0.0393)$ & $(0.8281)$ & $(0.0111)$ \\
\hline \multirow{2}{*}{ Age } & -- & -0.1558 & -0.0227 & $-0.7398^{*}$ & $-0.0098^{*}$ \\
& -- & $(0.0955)$ & $(0.0138)$ & $(0.3006)$ & $(0.0037)$ \\
\hline \multirow{2}{*}{ Age ${ }^{2}$ 10-2 } & -- & 0.1627 & 0.0237 & $0.7595^{*}$ & $0.0100^{*}$ \\
& -- & $(0.1194)$ & $(0.0173)$ & $(0.3269)$ & $(0.0040)$ \\
\hline \multirow{2}{*}{ Dependents } & -- & $0.5398^{*}$ & $0.0336^{*}$ & 0.9839 & 0.0130 \\
& -- & $(0.2373)$ & $(0.0138)$ & $(1.2401)$ & $(0.0169)$ \\
\hline Log Likelihood & -231 & -190 & & -75 & \\
\hline Observations & 458 & 458 & & 458 & \\
\hline
\end{tabular}

Dependent variable is one when wages, proprietorship, and farm earnings in 1991 are $\neq 0$, zero otherwise. Inheritance, wealth, and earnings are in millions of \$1989.

* Significant at the 5 percent level; ** Significant at the 10 percent level. 